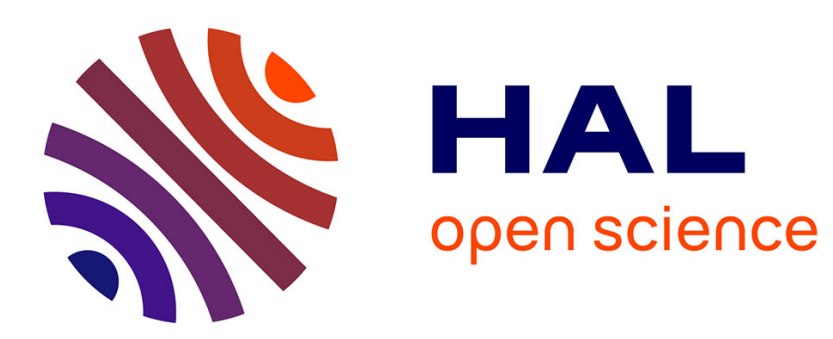

\title{
Geomorphic transport from historical shape from motion: Implications for tropical and alpine environments
}

Antoine Lucas, Eric Gayer

\section{- To cite this version:}

Antoine Lucas, Eric Gayer. Geomorphic transport from historical shape from motion: Implications for tropical and alpine environments. 2020. hal-02991802

\section{HAL Id: hal-02991802 \\ https://hal.science/hal-02991802}

Preprint submitted on 9 Nov 2020

HAL is a multi-disciplinary open access archive for the deposit and dissemination of scientific research documents, whether they are published or not. The documents may come from teaching and research institutions in France or abroad, or from public or private research centers.
L'archive ouverte pluridisciplinaire HAL, est destinée au dépôt et à la diffusion de documents scientifiques de niveau recherche, publiés ou non, émanant des établissements d'enseignement et de recherche français ou étrangers, des laboratoires publics ou privés. 


\section{The abstract}

We used historical aerial imagery in order to compute multi-decennial time-series of digital elevation models in order to
assess geomorphic transport in both alpine and tropical environments. We focused on two pristine examples namely The Rempart Canyon in Reunion Island and the Bossons glacier in the French Alps which share a limited accessibility (in time and the old analog photographic plate and the deformations due to the scanning of the archived images. In both cases, we emphasize the strong effect of extreme events over multi-decennial to century time-scales and discuss the implications in terms of landscape dynamics.

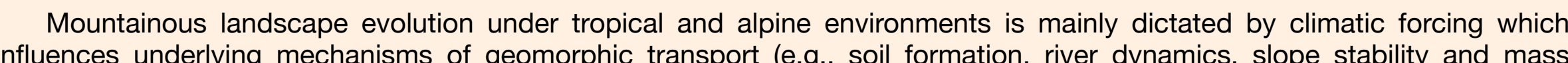
wasting). The time scale over which this influence acts ranges from seasonal to decennial time span. On the seasonal time scale, for accessible locations and when manpower is available, direct observations and field survey are the most useful and tandard approaches. While very limited studies have been focused on the the decennial and century scale due to

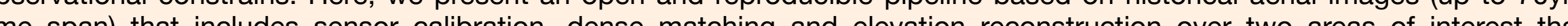

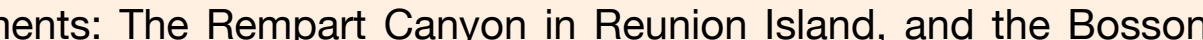
glacier in the French Alps share a limited accessibility (in time and space) that can be overcome only from remote-sensing. We reach unprecedented resolution: the aero-triangulation falls at sub-metric scale based on ground truth, which satellite images such as Pleiades. We emphasize the potential of assessing the effect of extreme events over multi-dest recial to satellite images such
century time-scales.

The method $\Rightarrow$ From scanned archived image to 3D cloud model
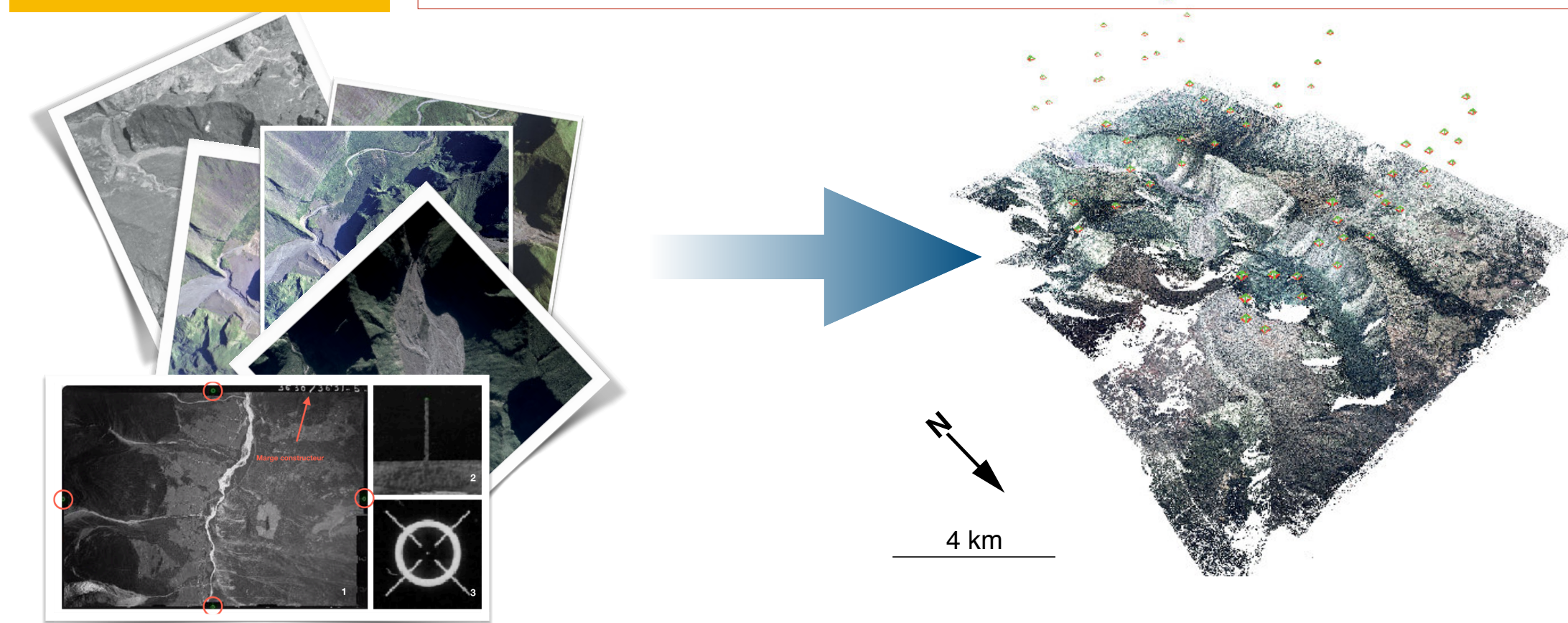

We integrated into the Open-Source MicMac [1] workflow new tools for automatic calibration and orientation of large archive of aerial scanned images

Unoriented and uncalibrated image registration
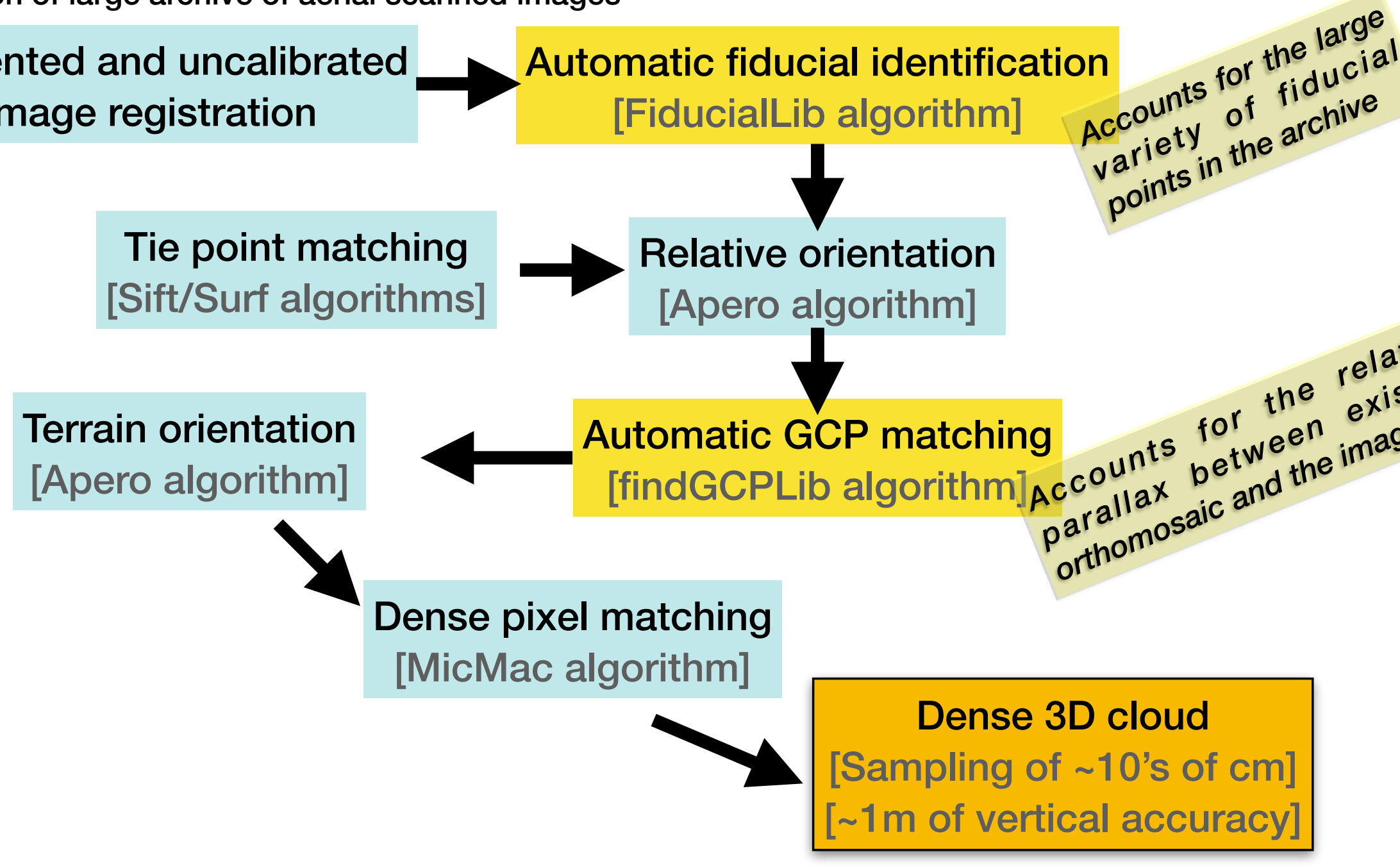

The tropical case $\rightarrow$ Highlight on mass transfer from hillslopes to the Remparts river (La Réunion)
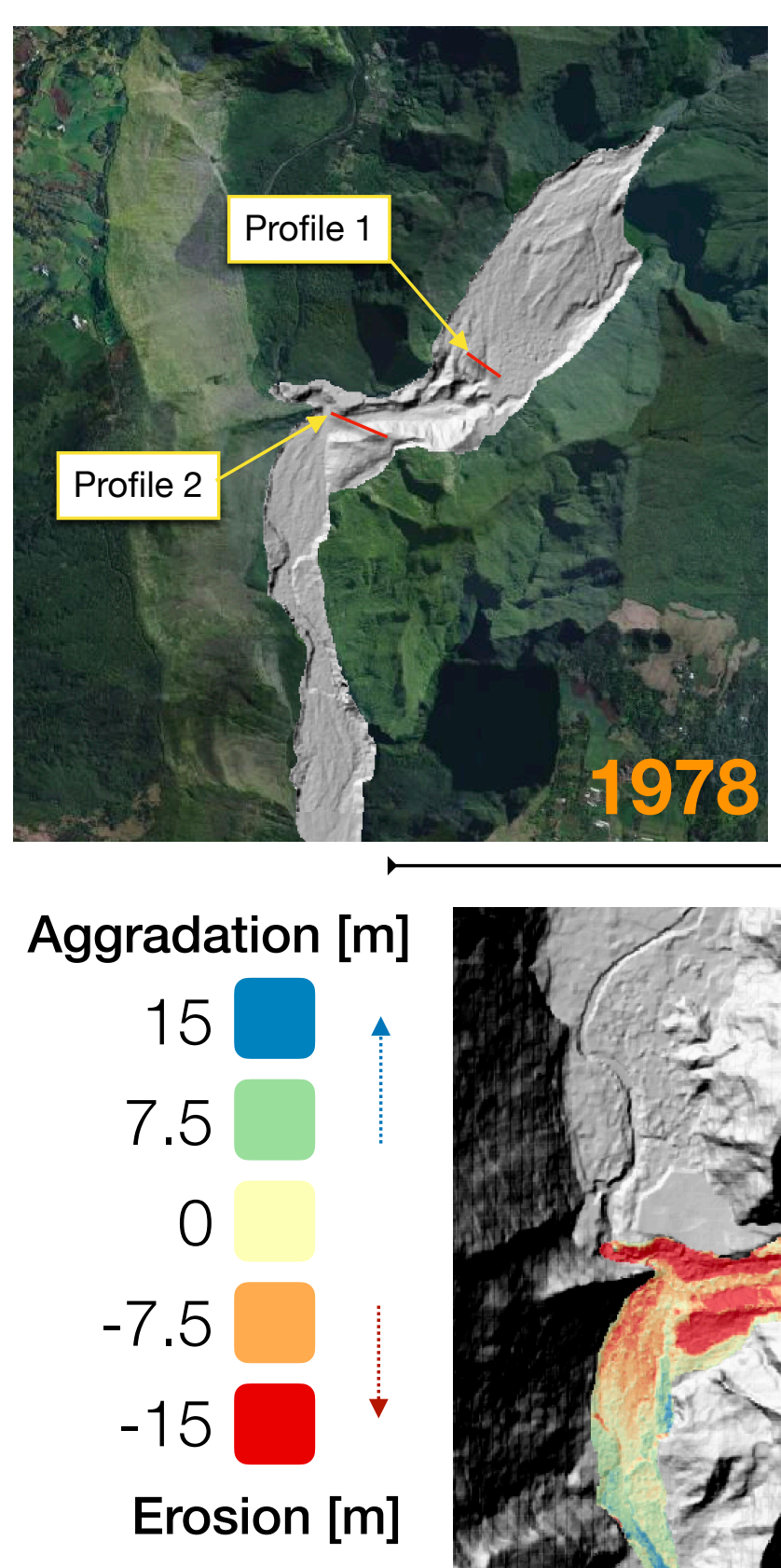

Aggradation $[\mathrm{m}]$

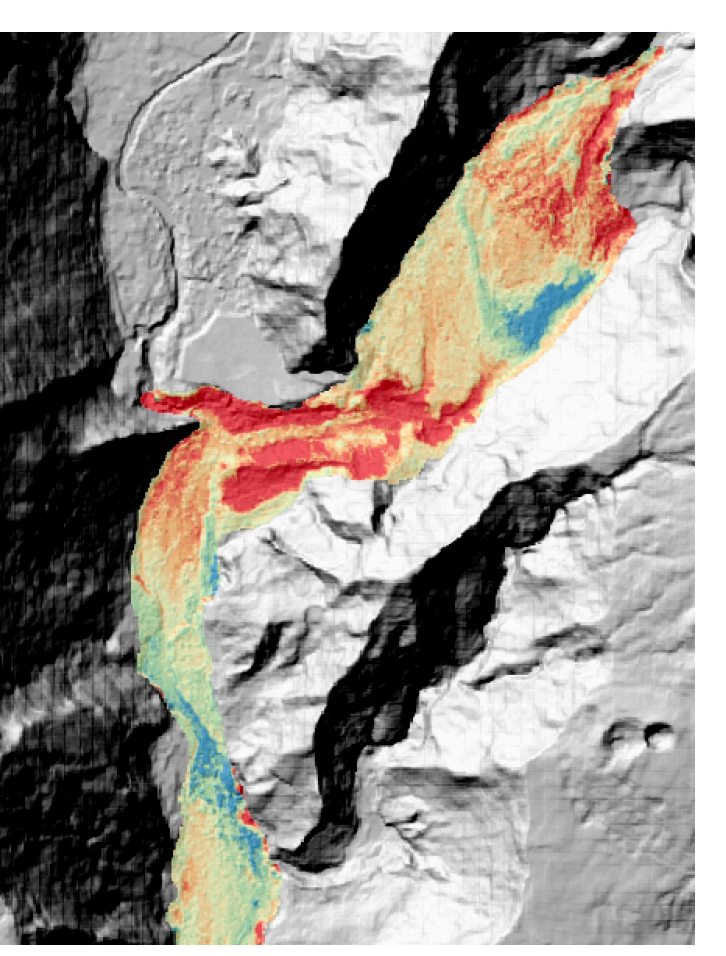

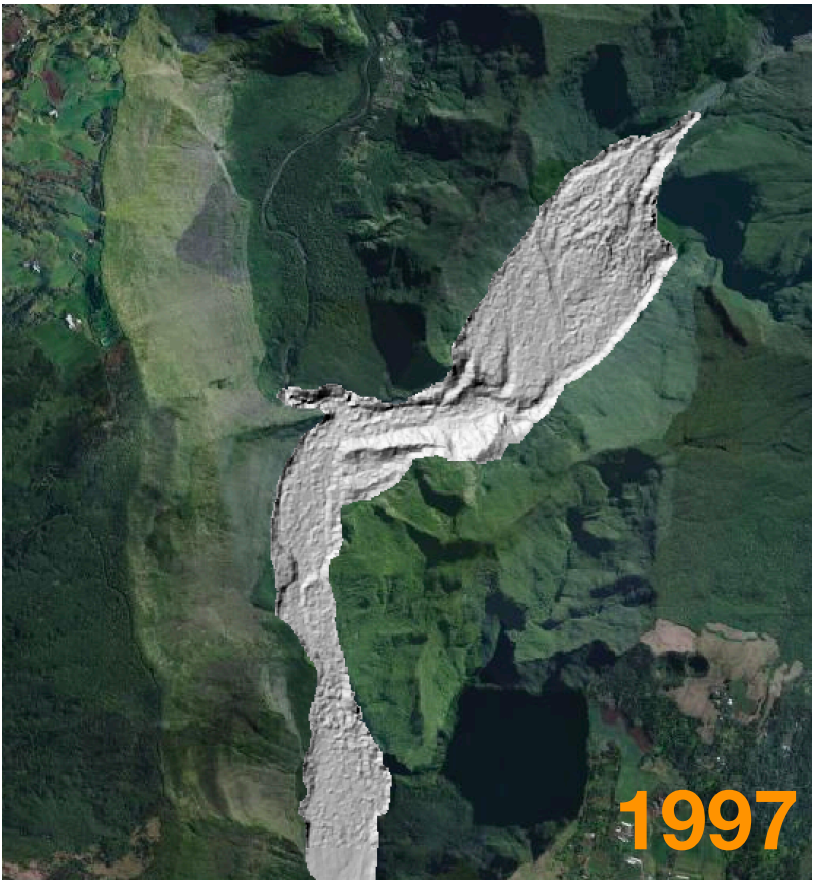

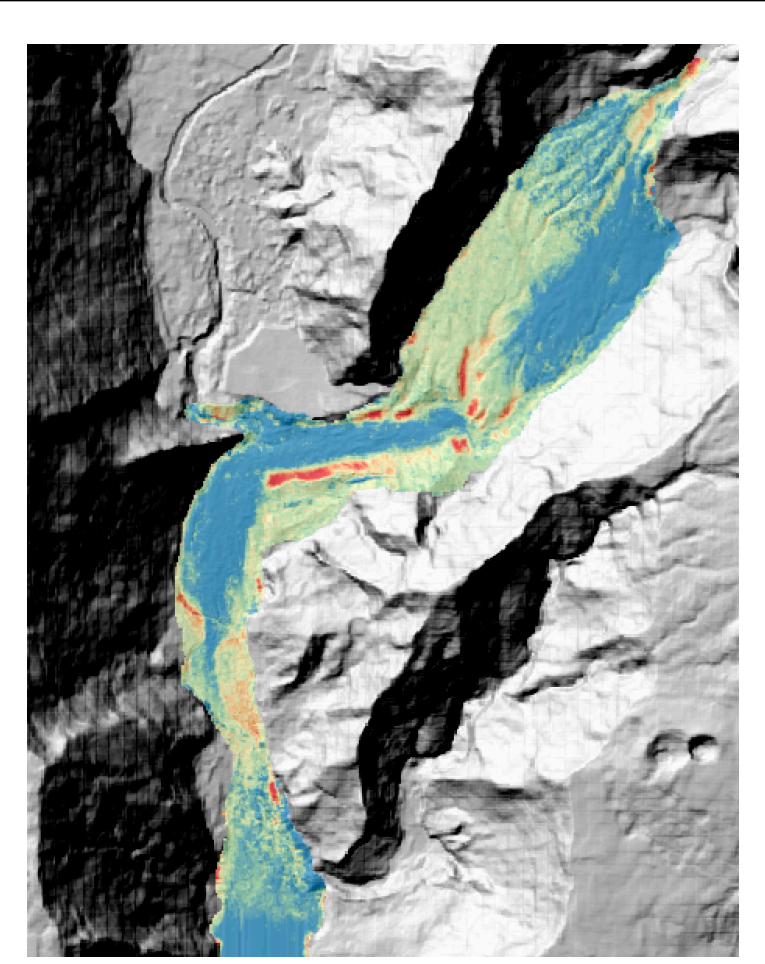

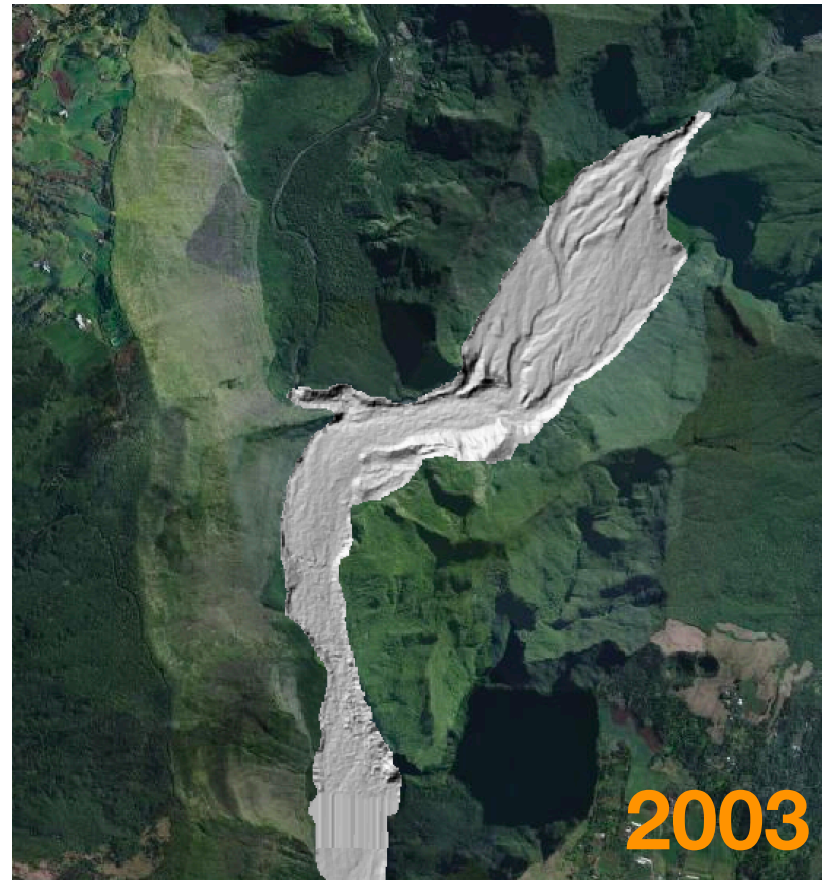

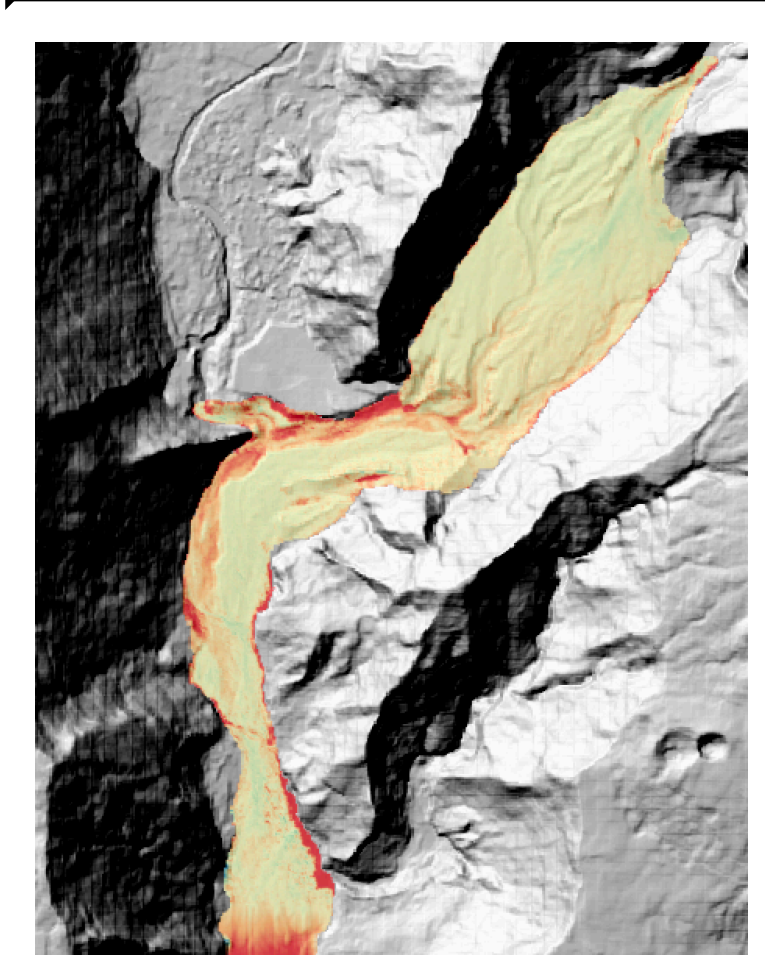

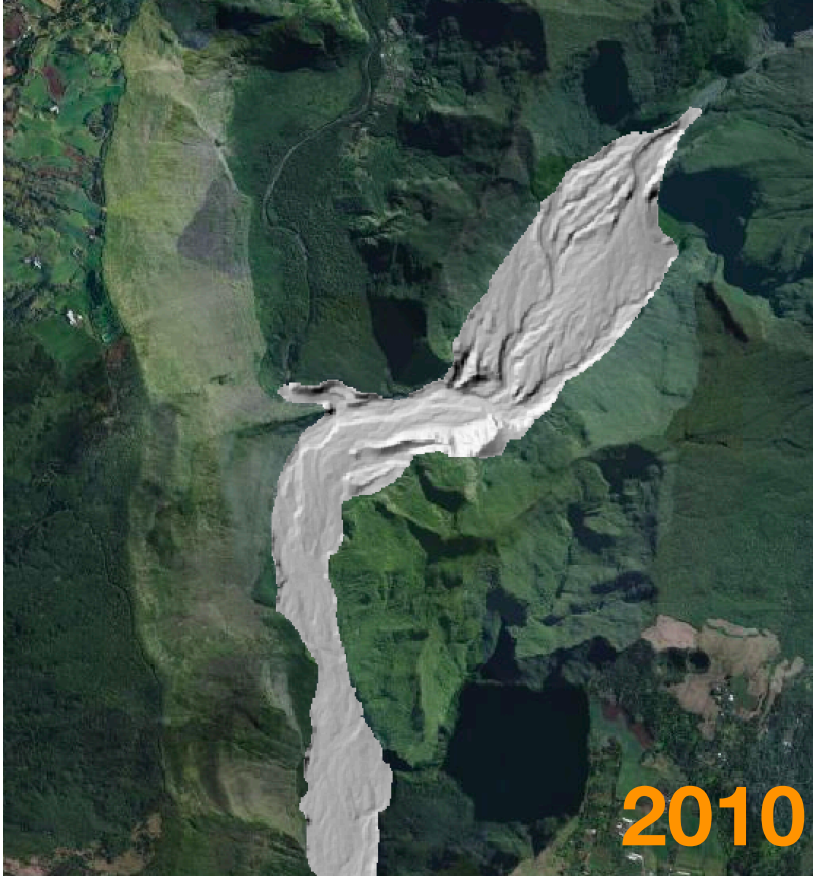

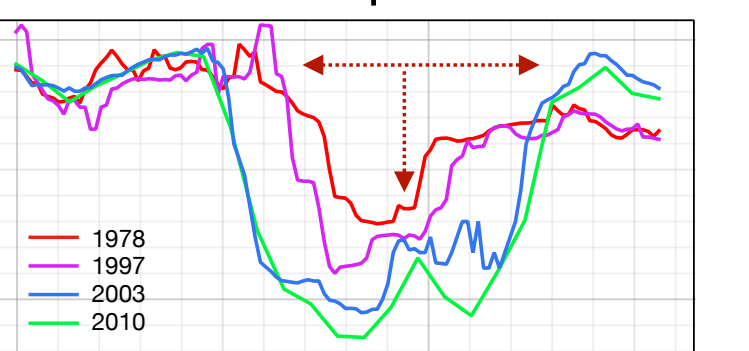

Evolution of profile 2

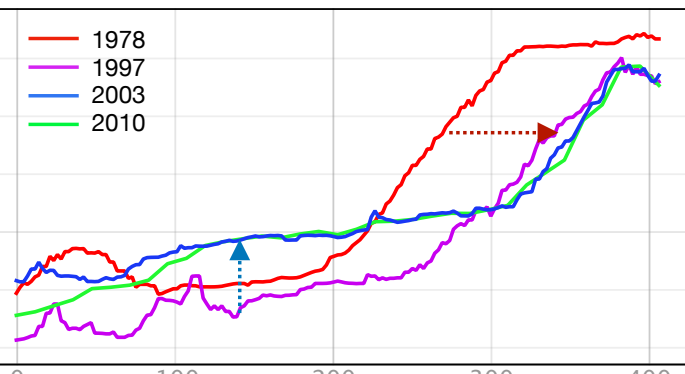

Evolution of profile 1

The alpine case $\Rightarrow$ Highlight on fast Bossons glacier reaction (Chamonix Mont-Blanc)

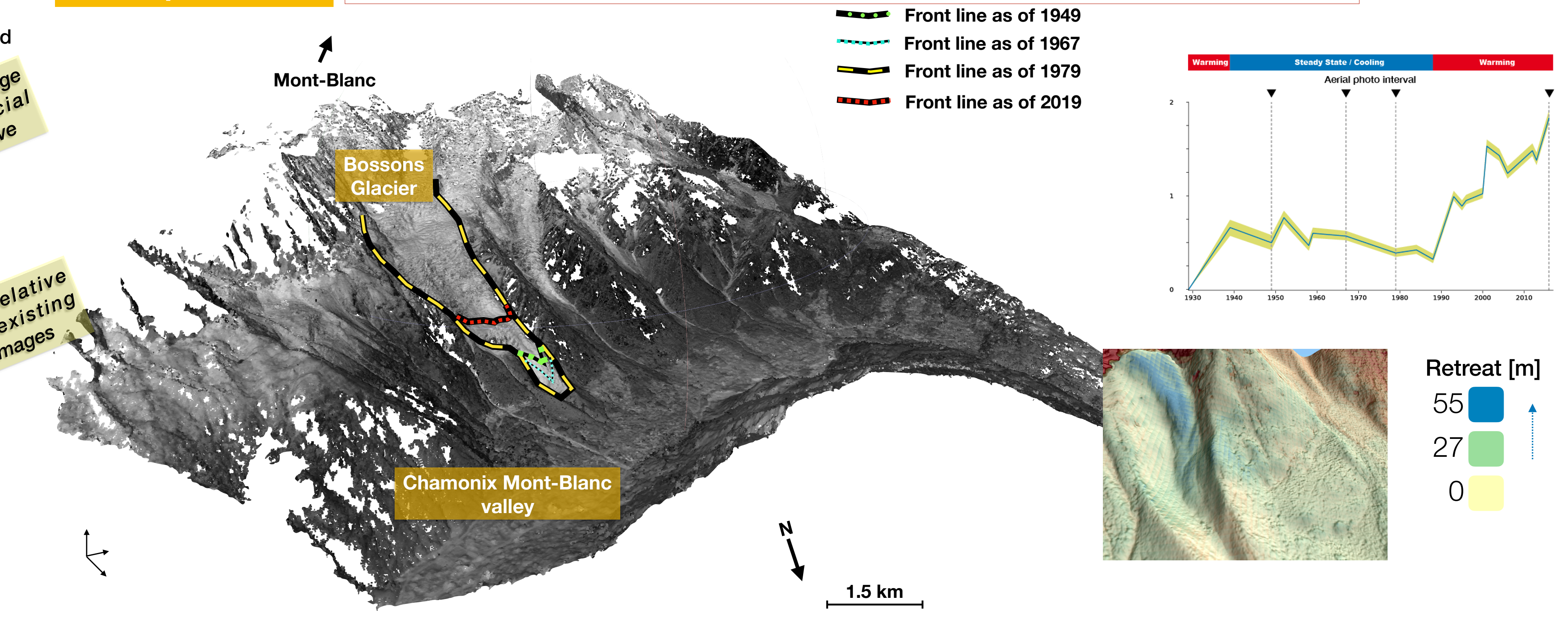

